\title{
HANP on renal damage during cardiac surgery
}

\author{
Guillermo Lema $^{1}\left(\mathbb{D} \cdot\right.$ Evelyn Borchert $^{1} \cdot$ Katia Gonzalez $^{1}$
}

Received: 30 August 2017 / Accepted: 17 November 2017 / Published online: 29 November 2017

(c) Japanese Society of Anesthesiologists 2017

Keywords Kidney $\cdot$ AKI $\cdot$ HANF

To the Editor:

I would like to make a number of comments on the article by Takahiro Moriyama [1] that was recently published in the Journal of Anesthesia.

1. Many research groups are looking for a therapy that can protect kidneys during surgery with cardiopulmonary bypass. Strategies involving the use of mannitol, fenoldopam, dexmedetomidina, high hematocrit, pulsatile flow, perfusion pressure, human natriuretic peptide, among others have been described, but none of these have shown benefits in patients at risk [1,2].

2. A plasma creatinine concentration of $\geq 1.5 \mathrm{mg} / \mathrm{dl}$ is the cut-off reported in most published studies. Therefore, I disagree with the plasma creatinine level on which the authors use to base their conclusions. In order to study renal protection in the population described, we may need a much larger number of patients, as the authors mentioned [1,2].

3. Plasma creatinine does not show any benefit of the protective drug used during treatment. The increase in enzyme levels also does not show any protective effects. Enzymes are released by the renal tubules due to injury.

This comment refers to the article available at doi:10.1007/ s00540-016-2284-0.

Guillermo Lema

glema@med.puc.cl; gmolema@gmail.com

1 Division of Anesthesiology, Pontificia Universidad Católica de Chile, Santiago, Chile
It has yet to be seen whether that injury becomes renal dysfunction [2].

4. Is cardiopulmonary bypass the main factor for renal failure? The incidence of renal failure in high-risk renal patients among patients undergoing off-pump surgery compared to those undergoing on-pump surgery is comparable [3]. Thus, a reno-protective strategy should include the peri-operative period. However, such a study would be almost impossible due to the type of patients and the diversity of therapies used in the post-operative period.

\section{References}

1. Moriyama T, Hagihara S, Shiramomo T, Nagaoka M, Iwakawa $S$, Kanmura Y.The protective effect of human atrial natriuretic peptide on renal damage during cardiac surgery. J Anesth. 2017;31:163-9.

2. Lema G, Canessa R, Urzua J. Renal protection: what should we aim for? J Cardiothorac Vasc Anesth. 2009;23:128-36.

3. Shroyer AL, Grover FL, Hattler B, Collins JF, McDonald GO, Kozora E, Lucke JC, Baltz JH, Novitzky D, for the Veterans Affairs Randomized On/Off Bypass (ROOBY) Study Group. Onpump versus off-pump coronary artery bypass surgery. N Engl J Med. 2009;361:1827-37. 